EDITORIAL

\title{
A SUSTENTABILIDADE NA PÓS-GRADUAÇÃO EM CONTABILIDADE
}

Na vida, algumas coisas são novas e importantes; outras são apenas importantes sem serem novas. Linha de pesquisa para a área acadêmica enquadra-se no segundo tipo. O grande risco de ser importante sem ser novo é que os pesquisadores são entes sedentos de novidades, sem tempo e, às vezes, sem paciência para dedicar tempo a algo de que alguém já tratou anteriormente. A conseqüência disso para a pesquisa e o ensino é o custo da baixa produtividade e eficácia e, traduzindo para a dimensão individual, o não sucesso na plenitude possível, com a continuidade no longo prazo dentro dos programas de pós-graduação. O sucesso, no longo prazo, pode ser traduzido pelo termo sustentabilidade.

Temos ótimo material humano na área de Contabilidade que poderia ter muito mais de que se orgulhar em termos de produtos. Por que isso nem sempre ocorre? Dentre outros motivos porque o aumento de eficiência exige sinergia e foco e isso só é obtido a partir de uma maior percepção de trabalho conjunto e direcionado por uma linha de pesquisa. A organização da pesquisa por linha tem ocorrido em outras áreas de conhecimento, dentro e fora das sociais aplicadas em que nos incluímos, e os pesquisadores em Contabilidade podem se beneficiar com o aprendizado existente, com certo nível de adaptação. Para começar, como definir a linha de pesquisa? Resgatando um debate histórico publicado na RAC em 2003, entre estudiosos do tema, no caso, Paulo Rogério Meira Menandro, Jairo Eduardo Borges-Andrade e Jaime Evaldo Fensterseifer, alguns pontos foram levantados, não como consenso, mas como direcionadores do debate. Esses pesquisadores iniciaram a discussão reconhecendo que não existe uma definição precisa e inquestionável de linha de pesquisa. Em certos momentos, argumentam que a flexibilidade e a frouxidão do conceito podem representar vantagem na adaptação às várias áreas do conhecimento. Entendem que a linha de pesquisa decorre de uma corrente teórica adotada e praticada por grupos. Resumiram linha de pesquisa como algo mais complexo e amplo do que um projeto e menos do que uma área de pesquisa. Deve ter como unidades básicas de ação as disciplinas e os projetos de pesquisa, e tais ingredientes proporcionam influências recíprocas ao longo do tempo.

Uma linha de pesquisa pode ter começo, meio e fim num horizonte temporal de longo prazo. Ela nasce quando tem projetos. Isso é fácil de perceber e entender, mas quando ela morre? Quando o interesse sobre os seus produtos se reduz, dilui, extingue. Aqui, cabe uma reflexão importante, pois essa percepção não é imediata nem fácil de ser gerenciada. Essa palavra é chave já que alguém tem que gerenciar, coordenar e cuidar da linha de pesquisa.

Cada linha de pesquisa deve ter um grupo de pesquisadores interessados, pesquisando, produzindo e gerando discípulos. A linha pode morrer ou transformar-se em decorrência do ambiente, da mudança de perspectiva das pessoas. Sintetizando, o DNA do pesquisador poderia ser encontrado na linha de pesquisa e ela permite que 0 conhecimento seja multiplicado, compartilhado, comunicado e utilizado. Em outras palavras, a linha de pesquisa funciona como a família, o grupo de amigos, a turma para o pesquisador. É a forma e o fórum nos quais os pesquisadores devem desenvolver suas atividades, trocar informações, identificar metodologias mais adequadas, discutir, avaliar trabalhos e pares etc.

O problema é que isso não acontece de graça. O gerenciamento de uma linha de pesquisa é fruto de trabalho e organização e cobrança. Se olharmos alguns dos problemas mais comuns dos Programas de Pós-Graduação, tais como a ausência de pesquisa, baixo volume de publicação e questões ligadas à qualidade dessa produção, falta de foco nos projetos, escassez de professores em regime de pesquisa, etc, etc, etc, certamente, iremos perceber que a solução ou a sua melhoria estão ligados, de alguma forma, ao gerenciamento das linhas de pesquisa. É a maneira que permite ao pesquisador, ao Programa ou ao grupo de pesquisa equilibrar o processo e o produto. A sustentabilidade do Programa, algo importante para toda a sociedade, é uma conseqüência.

Gostaria de mencionar que entendo que a orientação da CAPES aos Programas de Pós-Graduação, em termos de indicações sobre número mínimo de disciplinas, docentes, alunos, professores e mesmo titulados, como uma referência importante e indutora, mas que não deveria ser percebida apenas como uma forma burocrática de olhar o tema. É o início e não o fim do assunto.

Tenho certeza de que não estou pregando no deserto, mas quero resumir a minha opinião com um conselho: o lema forme a sua turma ou morra, a longo prazo, como visão de sustentabilidade do Pós-Graduação no país, deve preceder o muito conhecido lema publique ou morra. O segundo, no longo prazo, simplesmente vai ser uma conseqüência do primeiro.

Fábio Frezatti

Professor Livre-Docente do Departamento de Contabilidade e Atuária da FEA/USP 